\title{
KITAB MIZAN AL-QARB \\ (Telaah Metode Penentuan Awal Bulan Qamariah)
}

\author{
Nailur Rahmi', Yusri Akhimuddin²
}

\author{
1IAIN Batusangkar \\ e-mail: inelzena02@gmail.com \\ 2IAIN Batusangkar \\ e-mail: yusriakhimuddin@gmail.com
}

\begin{abstract}
The phenomenon of determining the time of the first day of Ramadan and the first day of Shawwal in Indonesia raises a prolonged folemic, each group has its own basis and methods. In West Sumatra region, there is a Tariqat Syatahariyah group which still has a large influence in the midst of the Minangkabau community, so they have their own method of determining the beginning of the Islamic month, the reckoning taqwim method. This method is found in the book of Mizan al-Qarb, which discusses the initial determination of the Qamariyah (lunar) system. This paper is more focused on how the dating system and the method of determining the beginning of the month of Qamariyah in the Mizan al-Qarb manuscript from the viewpoint of Falak and Astronomy. The method used is the field method and literature with the approach of Philology, Falak Science and Astronomy. The data source is the manuscript of Mizan al-Qarb found in Surau Calau Sijunjung. The documentation technique is used in data collection, with several stages: collection, selection, and criticism. With the findings of the manuscript Mizan al-Qarb with conditions that have begun to be damaged, then it is necessary to preserve the contents contained therein concerning the calendar and the method of determining the beginning of the Qamariyah which refers to the rukyat method, using the naked eye and not using the media, so it is concluded if the calculation starts from Thursday the result is the same as contemporary reckoning, if it starts Wednesday will be the first day difference with contemporary reckoning.
\end{abstract}

Kata kunci: Metode, awal bulan Qamariah, Kitab Mizan al Qarb.

\section{PENDAHULUAN}

Penanggalan adalah salah satu bentuk 1 pengetahuan manusia untuk menentukan waktu pada suatu wilayah. Pengetahuan ini selalu berkembang sesuai dengan tuntutan kebutuhan manusia. Karena itu, penanggalan pada awalnya tidaklah seragam untuk semua wilayah, tetapi dibuat terbatas sesuai dengan wilayah dan kondisi masyarakatnya. (Proudfoot, 2009)

Penanggalan dalam Islam sudah ada sejak dahulu, namun perbedaan sistem penanggalan tetap terjadi sampai sekarang, khususnya dalam menentukan 1 Ramadhan, 1 Syawal, dan 10 Dzulhijjah. Setiap kelompok mempunyai dan meyakini kebenaran sistem penanggalan yang diilmui mereka. Sayangnya sistem kalender yang diilmui setiap kelompok belum banyak yang diketahui oleh kelompok lain, terutama yang bersumber dari manuskrip, seperti yang terdapat dalam kitab Mizan al-qarb.

Prakteknya masih dijumpai di tengah masyarakat Propinsi Sumatera Barat, yakni metode penentuan awal 
bulan oleh Thariqat Syathariyah. Sampai saat ini aliran tersebut masih memiliki pengaruh yang kuat di kalangan masyarakat Sumatera Barat. Aliran ini tetap berkembang dan memilih memencilkan diri dari pemerintah dalam penentuan awal bulan Ramadhan dan Syawal khususnya karena mereka mempunyai system tersendiri dalam penentuan awal bulan Hijriyah. Metode tersebut dapat ditemukan dalam kitab Mizan al-Qarb yang membahas tentang system penanggalan dan metode penentuan awal bulan Hijriyah yang dikenal dengan metode hisab taqwim.

Berdasarkan penjelasan di atas penulis tertarik untuk menelusuri lebih jauh tentang sistem penanggalan dalan kitab Mizan al-Qarb yang dianut oleh aliran Syathariyyah. Tulisan ini akan ditelusuri sistem penanggalan, metode penetapan awal bulan Hijriyah dan akan dikaji dari sudut pandang Ilmu Falak.

\section{METODE PENELITIAN}

\section{Jenis dan Pendekatan Penelitian.}

Adapun jenis penelitian yang digunakan dalam penelitian ini adalah penelitian kepustakaan atau library research, yakni penelitian yang dilakukan melalui mengumpulkan data atau karya tulis ilmiah yang terkait dengan obyek penelitian atau pengumpulan data yang bersifat kepustakaan, atau telaah yang dilaksanakan untuk memecahkan suatu masalah yang pada dasarnya tertumpu pada penelaahan kritis dan mendalam terhadap bahan-bahan pustaka yang relevan. Pendekatan ilmu hisab digunakan dalam penghitungan sistem kalender dan penentuan awal bulan Hijriyah.

\section{Sumber Data}

Untuk menjawab permasalahan yang dikemukakan dalam penelitian ini, data yang dikumpulkan terdiri dari sumber primer yaitu sumber data yang langsung memberikan data kepada pengumpul data yaitu naskah Mizan Al-Qarb. Data sekunder yaitu sumber yang tidak langsung memberikan data kepada pengumpul data seperti artikel atau tulisan-tulisan lainnya tentang penentuan awal bulan Hijriyah.

\section{Teknik Pengumpulan Data}

Penelitian ini merupakan penelitian library research, maka teknik pengumpulan data yang digunakan dalam penelitian ini adalah pengumpulan data literatur yaitu dengan mengumpulkan bahan-bahan pustaka yang berkesinambungan (koheren) dengan objek pembahasan yang diteliti. Data yang ada dalam kepustakaan tersebut dikumpulkan dan diolah dengan cara:

1. Editing, yaitu pemeriksaan kembali dari data-data yang diperoleh terutama dari segi kelengkapan, kejelasan makna dan koherensi makna antara yang satu dengan yang lain.

2. Organizing yakni menyusun datadata yang diperoleh dengan kerangka yang sudah ditentukan.

3. Penemuan hasil penelitian, yakni melakukan analisis lanjutan terhadap hasil penyusunan data dengan menggunakan kaidah-kaidah, teori dan metode yang telah ditentukan sehingga diperoleh kesimpulan (inferensi) tertentu yang merupakan hasil jawaban dari rumusan masalah.

\section{Analisis Data}


Data yang diperoleh dari penelitian kepustakaan itu dianalisa dengan metode analisis komparasi yaitu: dengan cara membandingkan objek penelitian dengan konsep pembanding. Kemudian data yang telah diklasifikasi kemudian dipaparkan, disederhanakan menjadi kesimpulan yang singkat dan bermakna. Kesimpulan dalam penelitian ini merupakan temuan baru yang dapat berupa deskripsi atau gambaran suatu obyek yang sebelumnya masih remang-remang sehingga setelah diteliti menjadi jelas karena didukung data-data yang mantap dan akan menghasilkan kesimpulan yang kredibel.

\section{METODE PENENTUAN AWAL BULAN}

Penentuan awal bulan Islam merupakan prosesi yang dianggap penting dan sangat diperlukan bagi umat Islam. Sebab, penentuan awal bulan ini memiliki kaitan erat dengan beberapa ibadah yang wajib dijalankannya. Salah satu contoh dari beberapa ibadah tersebut ialah puasa Ramadhan.

Untuk mengetahui kapan dimulainya awal bulan Hijriyah, secara garis basar dapat dilakukan dengan cara-cara sebagai berikut:

\section{Ru'yah al-Hilâl}

Istilah $R u^{\prime}$ yah berasal dari fi'il $r a^{\prime} a$ yang berarti melihat. Kata $R u^{\prime} y a h$ mempunyai dua konotasi makna. Makna pertama ialah melihat dengan pandangan mata "Ru'yah Bashoriyyah". Sedangkan makna kedua melihat dengan ilmu pengetahuan " $R u^{\prime} y a h$ ilmiyah". Makna yang kedua 177 oku berarti mengetahui, menyangka, berpendapat, berpandangan, atau kata semacamnya.

Sedangkan hilâl dalam bahasa Arab diartikan bulan baru yang dalam konteks Indonesia disebut sebagai bulan sabit. Dalam hal ini terdapat 2 malam pada awal bulan. Menurut Imam Ibnu Mandzur, hilâl adalah bulan sabit yang tampak pada manusia saat awal bulan. Berbeda dengan Imam Ibnu Mulaqqin, ia mengartikan yang disebut hilâl hanya bulan dari tanggal 1 sampai tanggal 3, selebihnya disebut dengan al-Qamar.

Kementerian Agama yang dulu bernama Departemen Agama, mengistilahkan Ru'yah al-Hilâl hanya dengan sebutan ru'yah saja. Ru'yah perspektif Kementerian Agaman diartikan dengan melihat hilal pada saat matahari terbenam pada akhir bulan Hijriyah dalam rangka menentukan awal bulan berikutnya. Menurut Ahmad Sabiq pengertian $R u^{\prime} y a h$ alHilâl adalah kegiatan yang dilakukan seseorang atau sekelompok orang untuk melakukan pengamatan secara visual terhadap kemunculan hilal. Baik menggunakan mata langsung maupun dengan bantuan alat. Alat bantu visual yang biasa digunakan diantaranya teleskop, bino kular, dan kamera.

Sehingga dapat disimpulkan bahwa pengertian Ru'yah al-Hilâl adalah melihat munculnya hilal pada saat matahari tenggelam dan dilakukan pada tanggal 29 atau akhir bulan Hijriyah guna menetapkan awal bulan berikutnya. Baik melihat dengan 
mata telanjang atau dengan menggunakan alat bantu.

$\mathrm{Ru}^{\prime}$ yah al-Hilâl yang dilakukan dengan mata telanjang, biasa disebut dengan Ru'yah Bi al-Fi'li atau Bi alAini. Ru'yah Bi al-Fi'li merupakan praktek Ru'yah yang dilakukan pada masa Rasulullah SAW dan hanya melihat kearah ufuk barat saja tanpa ada kefokusan terhadap posisi tertentu. Sedangkan Ru'yah al-Hilâl yang didukung dengan alat bantu, dalam dunia astronomi dikenal dengan istilah observasi. Disebut dengan observasi karena sebelum melakukan Ru'yah, si pelaksana $\mathrm{Ru}^{\prime}$ yah sudah mengetahui posisi hilâl yang akan dilihat dengan cara melakukan perhitungan dengan metode hisâb. Sehingga dalam melakukan Ru'yah pandangan lebih terfokus pada posisi tertentu sesuai dengan hasil hitungan hisâb.

\section{Hisâb}

Secara bahasa, Hisâb diartikan dengan hitungan, perhitungan, arithmetic (ilmu hitung), reckoning (perhitungan), calculation (perhitungan), calculus (hitung), computation (perhitungan), estimation (penilaian, perhitungan), atau appraisal (penaksiran). Sedangkan arti Hisâb secara istilah adalah perhitungan benda-benda langit untuk mengetahui kedudukanya pada suatu saat yang diinginkan. Pendapat lain mengatakan, arti hisab adalah perhitungan terhadap posisi bendabenda langit. (Susiknan Azhari, 2005)

Sehingga dapat disimpulkan bahwa yang dimaksud hisab awal bulan Hijriyah adalah perhitungan terhadap posisi matahari atau bulan guna menentukan kedudukan dua benda tersebut pada saat-saat tertentu sehingga diketahui kapan dimulainya awal bulan Hijriyah.

\section{DASAR HUKUM HISAB DAN RUKYAT}

Pada dasarnya praktik $R u^{\prime} y a ̂ h$ dan hisâb memiliki dasar hukum yang sama. Hanya saja keduanya memiliki pemahaman berbeda mengenai tafsiran makna yang terkandung didalam dasardasar tersebut. Diantara dasar-dasar 178 okum yang digunakan dalam melakukan ru'yâh dan hisâb adalah:

Firman Allâh SWT yang disebutkan dalam al-Qur'ân al-Karîm:

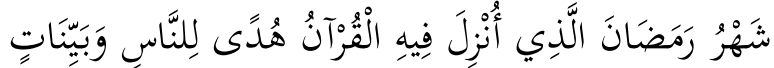

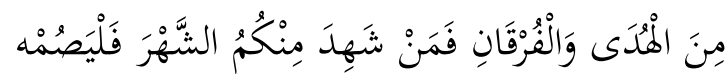

"(Beberapa hari yang ditentukan itu ialah) bulan Ramadhan, bulan yang di dalamnya diturunkan (permulaan) Al-Quran sebagai petunjuk bagi manusia dan penjelasanpenjelasan mengenai petunjuk itu dan pembeda (antara yang hak dan yang bathil). Karena itu, barangsiapa di antara kamu hadir (di negeri tempat tinggalnya) di bulan itu, maka hendaklah ia berpuasa pada bulan itu". (Q.S. al-Baqorah [2]:185)

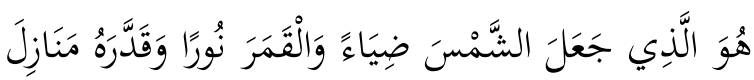

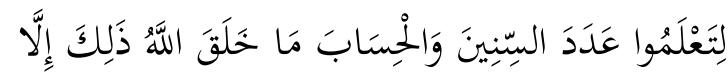

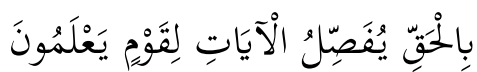

"Dia-lah yang menjadikan matahari bersinar dan bulan bercahaya dan ditetapkan-Nya manzilah-manzilah (tempat-tempat) bagi perjalanan bulan itu, supaya kamu mengetahui bilangan tahun dan perhitungan (waktu). Allâh tidak menciptakan yang demikian itu melainkan dengan hak. Dia menjelaskan tanda-tanda (kebesaran-Nya) kepada orang-orang yang mengetahu". (Q.S. Yunus [10]:5)

Selain itu Rasulullah SAW juga bersabda: 


$$
\begin{aligned}
& \text { باب قول النبي صلى الله عليه و سلم ( إذا رأيتم الهلال } \\
& \text { فصوموا وإذا رأيتموه فأفطروا ) }
\end{aligned}
$$

"Ketika kalian melihat hilâl. Maka berpuasalah. Dan ketika kalian melihat hilâl maka berbukalah".

Ayat dan Hadits di atas menjelaskan bahwa Allah telah memberi petunjuk kepada mereka yang berilmu dengan adanya matahari, bulan, siang, dan malam, supaya manusia 179 oku mengetahui hitungan waktu. Ayat dan hadits itulah yang dijadikan dasar penggguna'an ilmu hisâb dan Ru'yâh.

\section{PENANGGALAN MASEHI}

Sejak 700 tahun Sebelum Masehi (SM), bangsa Babilonia telah mengenal ekliptika atau bidang edar matahari, dan telah menetapkan lamanya 1 tahun yaitu, lamanya waktu buat satu kali matahari beredar di ekliptika adalah 365,25 hari yang disebut dengan Tarikh Yulian. Tarikh Yulian berasal dari nama Julius Caesar yaitu orang yang mula-mula menentukan cara perhitungan penggalan itu pada tahun $46 \mathrm{SM}$.

Tarikh Yulian dihitung menurut lamanya bumi mengelilingi matahari dalam 1 tahun yaitu 365.25 hari, 5 jam 48 menit 46 detik $=365,242199$ hari atau dibulatkan menjadi 365.25 hari. Kalau dibulatkan 365.25 hari tentu terdapat ketekoran sebanyak 0.007801 hari tiap tahun. Oleh Paus Gregarious XIII pada tahun 1582 Masehi, penanggalan Yulius Caesar itu dibetulkan yaitu sejak 46 tahun SM - 1582 Masehi telah terdapat kesalahan perhitungan penanggalan yaitu $1628 \times 0.007801$ hari $=12.700028$ hari atau 13 hari. Angka 13 hari ini disebut ralat Gregorian. Memang dalam kalender masehi 1 tahun $=365$ hari, yang 0.25 hari setelah 4 tahun akan menjadi 1 hari yang dihadiahkan ke bulan Februari, sehingga umur bulan Februari menjadi 29 hari pada tahun ke 4 . Tahun ke 4 ini disebut tahun kabisat atau tahun panjang. Namun demikian masih terdapat kesalahan 0.007801 hari pertahun. Setelah 400 tahun terdapat kesalahan sebanyak $400 \times 0.007801$ hari $=3.1204$ hari, oleh sebab itu tahun yang habis dibagi 400 adalah tahun Kabisat. Dengan demikian tahun Kabisat adalah:

1) Tahun yang habis dibagi 4 , misalnya tahun 1992,1996,2004,2008,2012,...dst

2) Tahun kelipatan 100, habis dibagi 400, misalnya tahun 2000, 2400,2800,3200,3600,..dst

\section{Cara menentukan hari jatuhnya Satu Tanggal}

Untuk menentukan hari jatuhnya suatu tanggal pada tahun masehi diperlukan 3 indeks, yaitu:

1. Indeks tanggal (d)

Nilai d ini sama dengan angka tanggal dari bulan-bulan pada tahun masehi

2. Indeks bulan (m) yang nilainya sbb: 


\begin{tabular}{|c|c|}
\hline$a$ & $\begin{array}{l}\text { Indeks Bulan Januari }=6 \\
\text { Umur Bulan januari }=31 \\
\text { Jumlah } 37 \bmod (7)=2\end{array}$ \\
\hline $\mathrm{b}$ & $\begin{array}{l}\text { Indeks Bulan Februari }=2 \\
\text { Umur Bulan Februari }=\underline{28} \\
\text { Jumlah } 30 \bmod (7)=2\end{array}$ \\
\hline c & $\begin{array}{l}\text { Indeks Bulan Maret }=2 \\
\text { Umur Bulan Maret }=31 \\
\text { Jumlah } 33 \bmod (7)=5\end{array}$ \\
\hline $\mathrm{d}$ & $\begin{array}{l}\text { Indeks Bulan April = } 5 \\
\text { Umur Bulan April = } 30 \\
\text { Jumlah } 35 \bmod (7)=0\end{array}$ \\
\hline $\mathrm{e}$ & $\begin{array}{l}\text { Indeks Bulan September }=4 \\
\text { Umur Bulan September }=30 \\
\text { Jumlah } 34 \bmod (7)=6\end{array}$ \\
\hline $\mathrm{f}$ & $\begin{array}{l}\text { Indeks Bulan Oktober }=6 \\
\text { Umur Bulan Oktober }=31 \\
\text { Jumlah } 37 \bmod (7)=2\end{array}$ \\
\hline $\mathrm{g}$ & $\begin{array}{l}\text { Indeks Bulan Mei }=0 \\
\text { Umur Bulan } \operatorname{mei}=31 \\
\text { Jumlah } 31 \bmod (7)=3\end{array}$ \\
\hline $\mathrm{h}$ & $\begin{array}{l}\text { Indeks Bulan Juni }=3 \\
\text { Umur Bulan Juni }=30 \\
\text { Jumlah } 33 \bmod (7)=5\end{array}$ \\
\hline $\mathrm{i}$ & $\begin{array}{l}\text { Indeks Bulan Juli }=5 \\
\text { Indeks Bulan Juli }=5 \\
\text { Jumlah } 36 \bmod (7)=1\end{array}$ \\
\hline $\mathrm{j}$ & $\begin{array}{l}\text { Indeks Bulan Agustus= } 1 \\
\text { Umur Bulan Agustus= } 31 \\
\text { Jumlah } 32 \bmod (7)=4\end{array}$ \\
\hline $\mathrm{k}$ & $\begin{array}{l}\text { Indeks Bulan Nofember }=2 \\
\text { Umur Bulan Nofember }=30 \\
\text { Jumlah } 32 \bmod (7)=4\end{array}$ \\
\hline 1 & $\begin{array}{l}\text { Indeks Bulan Desember }=4 \\
\text { Umur Bulan Desember }=31 \\
\text { Jumlah } 35 \bmod (7)=0\end{array}$ \\
\hline
\end{tabular}

3. Indeks Tahun (y) $\mathrm{y}=\mathrm{Y}+\operatorname{int}(\mathrm{Y} / 4) \bmod 7$

Ketiga indeks dijumlahkan: $\mathrm{J}=\mathrm{d}+\mathrm{m}+$ $\mathrm{y}$, hari jatuhnya penggalan itu:
$\mathrm{H}=\mathrm{J} \bmod (7)$ setelah dapat nilai $\mathrm{H}$, hari jatuhnya hari lihat table di bawah ini:

\begin{tabular}{|c|c|c|}
\hline No & Nilai H & Nama Hari \\
\hline 1 & 1 & Minggu \\
\hline 2 & 2 & Senin \\
\hline 3 & 3 & Selasa \\
\hline 4 & 4 & Rabu \\
\hline 5 & 5 & Kamis \\
\hline 6 & 6 & Jimat \\
\hline 7 & 0 & Sabtu \\
\hline
\end{tabular}

Kalau berada pada tahun kabisat, indeks bulan Januari dan Februari, tahun kabisat itu dikurangi 1, dari yang tertera di atas. Untuk lebih jelasnya perhatikan table di bawah ini:

\begin{tabular}{|c|l|c|c|}
\hline No & Nama Bulan & $\begin{array}{l}\text { Tahun } \\
\text { Biasa }\end{array}$ & $\begin{array}{l}\text { Tahun } \\
\text { Kabisat }\end{array}$ \\
\hline 1 & Januari & 6 & 5 \\
\hline 2 & Februari & 2 & 1 \\
\hline 3 & Maret & 2 & 2 \\
\hline 4 & April & 5 & 5 \\
\hline 5 & Mei & 0 & 0 \\
\hline 6 & Juni & 3 & 3 \\
\hline 7 & Juli & 5 & 5 \\
\hline 8 & Agustus & 1 & 1 \\
\hline 9 & September & 4 & 4 \\
\hline 10 & Oktober & 6 & 6 \\
\hline 11 & November & 2 & 2 \\
\hline 12 & Desember & 4 & 4 \\
\hline
\end{tabular}

\section{METODE RUKYAT}

Rukyat artinya melihat, lengkapnya Rukyatul Hilal adalah suatu kegiatan atau usaha melihat hilal di langit (ufuk) 
sebelah barat sesaat setelah matahari terbenam menjelang awal bulan baru.

Hal ini dapat dilakukan dengan mata biasa, teropong dan teodolite. Rukyat dengan teodholit langkah-langkahnya sebagi berikut.

1. Siapkan data tinggi hilal, azimuth hilal, lama hilal, dan waktu matahari terbenam

2. Pasang teodholit pada tiang penyangganya

3. Stel theodolit (dengan 3 skrup di bagian bawah) hingga bena-benar datar (perhatikan water pass)

4. Arahkan teleskop pada ufuk barat, kemudian stel diafragmanya hingga ufuk terlihat paling cerah

5. Pasang kompas di puncak theodolite atau ditempat yang telah disediakan

6. Arahkan sasaran teodolit ke titik barat, dengan mengintai paa lobang kompas (angka kompas menunjukkan 270 ) perbaiki variasi magnet

7. Kuncilah theodolit (dengan horizontal clamp dikencangkan) agar tidak bergerak secara horizontal

8. Hidupkan theodolit dengan memindahkan tombol power ke posisi "on"

9. Tunggu sejenak hingga display (kaca penyaji) menampilkan angka; (VA= berapa saja; $\mathrm{HA}=00^{\circ} 00^{\circ} 00^{\circ} ; \mathrm{VA}=$ Vertical Angle; dan HA=Horizontal Angle)

10. Perhatikan azimuth hilal menurut hisab, apakah posisi hilal di sebelah utara setitik barat atau di selatannya. Apabila posisi hilal di utara titik barat, maka tekan L/R hingga tampil " $R$ ', apabila hilal disbelah selatan titik barat maka tampilkan 'L'
11. Bukalah kunci horizontal tadi (kendurkan skrup horizontal clamp)

12. Arahkan sasaran theodolit sebesar azimuth hilal (sasaran theodolit ke azimuth hilal ini dapat dipantau pada display) kemudian kuncilah kembali dengan horizontal clamp

13. Apabila angka pada display kurang tepat maka gerak horizontal theodolit dapat diperhalus dengan memutar mutar skrup penyetel horizontal (horizontal tangent clamp)

14. Arahkan sasaran teleskop tepat pada ufuk mar'I kemudian periksalah angka pada dosplay $(\mathrm{VA}=\ldots .$. ?) catat angka itu dan gunakan untuk mengoreksi tinggi hilal hasil hisab

15. Gerakkan teleskop ke atas-bawah hingga display (VA) menunjukkan angka tinggi hilal setelah dilakukan koreksi tadi

16. Kuncilah dengan pengunci vertical (vertical clamp), apabila angka pada display kurang tepat maka teleskop dapat digerakkan secara halus dengan vertical tangent clamp. (Muhyiddin Khazin: 2005)

Posisi hilal ketika matahari terbenam sudah terbidik dengan theodolit yaitu abila di lihat dari lubang pengincar maka hilal berada di titik focus lensa theodolit.

\section{SEKILAS TENTANG TARIKAT NAQSABANDIYAH}

Tarikat Naqsabandiyah merupakan salah satu aliran yang berkembang secara luas pada abad ke 19. Aliran ini tidak hanya berkembang di Indonesia, tetapi juga di Timur Tengah. Banyak amalan- 
amalan yang dilakukan oleh pengikut tarikat ini, yang pada umunya bertujuan untuk Tazkiyat al-Nafs (penyucian jiwa). Di antaranya adalah zikir yaitu mengingat Allah dengan mengucapkan kalimat-kalimat tayyibah. Dengan banyak melakukan zikir jiwa akan tenang dan damai. (Muhtador, 2017)

Aliran ini berkembang di beberapa wilayah di Indonesia termasuk di sumatera Barat, diantaranya Pasaman Barat, yang berkembang cukup pesat dengan berbagai aliran yang dikembangkan.

\section{METODE PENENTUAN AWAL BULAN DALAM NASKAH MIZAN AL-QARB}

\section{Hisab}

Dalam Naskah Mizan Al-Qarb ditemukan bahwa, hisab disebut juga dengan Taqwim. Metode Taqwim dan Rukyat merupakan cara yang digunakan dalam penentuan awal bulan Hijriyah. Tapi metode Hisab bukanlah acuan dalam penentuan awal bulan Hijriyah, tetapi hanya untuk mengetahui kapan melakukan rukyat.

Dalam melakukan hisab ada dua jenis taqwim yang populer dipedomani yakni:

1. Menghitung jatuhnya awal bulan dengan memulai hitungan pada hari rabu dikenal dengan istilah taqwin arba'iyah.

2. Menghitung jatuhnya awal bulan dengan memulai hitungan pada haru kamis dikenal dengan istilh taqwin khamsiyah. Seperti tercantum pada ungkapan di bawah ini: untuk melakukan hisab ada dua data yang dibutuhkan, yaitu huruf tahun yang delapan dan huruf bulan yang dua belas.
Dari ungkapan di atas dapat dipahami data huruf tahun yang delapan seperti terlihat pada table di bawah ini:

\begin{tabular}{|l|l|l|l|l|l|l|l|}
\hline D & W & B & D & Z & J & H & A \\
\hline 1 & 6 & 2 & 4 & 7 & 3 & 5 & 1 \\
\hline
\end{tabular}

Data Bulan yang Dua belas seperti terlihat pada table di bawah ini:

\begin{tabular}{|l|l|l|l|l|l|l|l|l|l|l|l|}
\hline J & A & Z & H & D & B & A & W & H & J & B & Z \\
\hline 3 & 1 & 7 & 5 & 4 & 2 & 1 & 6 & 5 & 3 & 2 & 7 \\
\hline
\end{tabular}

Untuk mengetahui hasil hisab berdasarkan metode taqwim khamsiyah dan taqwim arba'iyah dapat dilihat pada contoh dibawah ini:

a. Tanggal 1 Muharam $1434 \mathrm{H}$

1) Tahun yang dicari dibagi huruf tahun yang delapan

$8 / 1434=179$

$\underline{8-}$

63

$\underline{56}$

74

$\underline{72}$

2

2) Sisa pembagian 1 dihitung pada tahun yang delapan dimulai dari "ha"

\begin{tabular}{|l|l|l|l|l|l|l|l|}
\hline D & W & B & D & Z & J & H & A \\
\hline 1 & 6 & 2 & 4 & 7 & 3 & 5 & 1 \\
\hline
\end{tabular}

3) Hasil perhitungan "ja" ditambah nilai bulan yang dicari dari dari huruf bulan yang dua belas

$=\mathrm{j}+\mathrm{za}$

$=3+7$ 
$=10$

4) Hasil penjumlahan 10 dihitung mulai dari hari kamis, maka jatuh pada sabtu. Kalau dihitung pada hari rabu maka awal bulan jatuh pada hari jumat.

b. Tanggal 1 Ramadhan $1434 \mathrm{H}$

1) Tahun yang dicari dibagi huruf tahun yang delapan

$8 / 1434=179$

$$
\begin{aligned}
& \frac{8-}{63} \\
& \frac{56}{74} \\
& \frac{72}{2}
\end{aligned}
$$

2) Sisa pembagian 2 dihitung pada tahun yang delapan dimulai dari "ha"

\begin{tabular}{|l|l|l|l|l|l|l|l|}
\hline $\mathrm{D}$ & $\mathrm{W}$ & $\mathrm{B}$ & $\mathrm{D}$ & $\mathrm{z}$ & $\mathrm{J}$ & $\mathrm{H}$ & Alif \\
\hline 1 & 6 & 2 & 4 & 7 & 3 & 5 & 1 \\
\hline
\end{tabular}

3) Hasil perhitungan " $z$ " ditambah nilai bulan yang dicari dari huruf bulan yang dua belas

$$
\begin{aligned}
& =j+z \\
& =3+10 \\
& =13
\end{aligned}
$$

4) Hasil penjumlahan 13 dihitung mulai dari hari kamis, maka jatuh pada hari Selasa. Kalau menghitung dari hari rabu maka awal bulan jatuh pada hari senin.

a. Tanggal 1 Syawal $1434 \mathrm{H}$

1) Tahun yang dicari dibagi huruf tahun yang delapan

$8 / 1434=179$ $\underline{8-}$

63

$\frac{56}{74}$

$\frac{72}{2}$

2) Sisa pembagian 2 dihitung pada tahun yang delapan dimulai dari "ha"

\begin{tabular}{|l|l|l|l|l|l|l|l|}
\hline D & W & B & D & z & J & H & Alif \\
\hline 1 & 6 & 2 & 4 & 7 & 3 & 5 & 1 \\
\hline
\end{tabular}

3) Hasil perhitungan " $z$ " ditambah nilai bulan yang dicari dari huruf bulan yang dua belas

$=\mathrm{j}+\mathrm{z}$

$=3+7$

$=10$

4) Hasil penjumlahan 10 dihitung mulai dari hari kamis, maka jatuh pada hari Sabtu.Kalau dihitung pada rabu maka awal bulan jatuhpada hari jumat

b. Tanggal 1 Zulhijjah $1434 \mathrm{H}$

1) Tahun yang dicari dibagi huruf tahun yang delapan

$8 / 1434=179$

$\underline{8-}$

63

$\frac{56}{74}$

$\frac{72}{2}$ 
2) Sisa pembagian 2 dihitung pada tahun yang delapan dimulai dari "ha"

\begin{tabular}{|l|l|l|l|l|l|l|l|}
\hline D & W & B & D & z & J & H & Alif \\
\hline 1 & 6 & 2 & 4 & 7 & 3 & 5 & 1 \\
\hline
\end{tabular}

3) Hasil perhitungan " $z$ " ditambah nilai bulan yang dicari dari huruf bulan yang dua belas

$$
\begin{aligned}
& =j+j \\
& =3+3 \\
& =6
\end{aligned}
$$

4) Hasil penjumlahan 6 dihitung mulai dari hari kamis, maka jatuh pada hari Selasa. Kalau dihitung mulai hari Rabu maka jatuh pada hari Senin.

\section{Rukyat}

Dalam penentuan awal bulan Hijriyah dalam Nasakah Mizan AlQarb ditemukan bahwa dasar hukum yang digunakan adalah hadis riwayat Bukhari Muslim yaitu: ; "Jangan kamu berpuasa sampai kamu melihat hilal dan jangan berbuka sehingga kamu melihat bulan dan berawan (cukupkan)". Dalam satu riwayat, bulan 29 malam jangan kamu puasa sampai kamu I melihatnya, jika kamu dilingkupi awan maka sempurnakan bilangan 30 hari mutafqu 'alaihi

Sya'ban, didasarkan sabda Nabi saw: Berpuasalah kalian karena melihat hilal, dan berbukalah karena melihat hilal, jika terhalang olehmu (melihatnya) maka sempurnakan bilangan Sya'ban 30 hari (baik mengetahui hilal Sya'ban dengan melihatnya sebelum taqwim atau dengan hisab), dan ketetapan melihatnya setelah terbenam oleh seorang yang adil. 'Adlan berpedapat syaratnya satu yaitu sifat 'adil, tidak boleh budak dan wanita, karena keduanya tidak bisa adil dalam kesaksian.
Dalam pelaksanaan rukyat hilal, dilakukan dengan cara manual atau tanpa media teknologi. Lokasi yang biasa digunakan sebagai tempat merukyat oleh penganut kitab ini adalah, untuk daerah pantai, biasanya, kelompok Syattariyah melakukannya di pinggir pantai pada akhir bulan Sya'ban, sedangkan di daerah pedalaman dilakukan di pusat Syattariyah yang berada di daerah ketinggian, seperti pusat Syattariyah Koto Tuo Kabupaten Agam, dan di Calau, Sijunjung.

Langkah-langkahnya adalah sebagai berikut:

1. Pengamatan hilal dilakukan pada tanggal 29 setiap bulannya.

2. Melihat hilal langsung dengan mata telanjang di tempat ketinggian

3. Jika hilal tidak Nampak maka digenapkan 30 hari, baik pengamatan dilakukan sebelum melakukan taqwim/hisab.

4. Jika hasil taqwim sama dengan rukyat, maka tidak wajib menyempurnakan 30 hari

5. Mendahulukan hasil pengamatan daripada taqwim/hisab.

METODE PENENTUAN AWAL BULAN DALAM NASKAH MIZAN AL-QAR DIKAJI MENURUT ILMU FALAK

Di bawah ini akan di lihat beberapa contoh perhitungan penentuan awal bulan berdasarkan hisab hakiki untuk wilayah Batusangkar:

a. 1 Muharam $1434 \mathrm{H}$

Penyesuaian tanggal ke Masehi

$\begin{aligned} \mathrm{A}= & \begin{array}{l}\text { Jumlah hari sejak Nabi Isa } \\ \text { lahir sampai } \\ \\ \text { Muhammad Hijrah=227016 }\end{array} \\ \mathrm{B}= & \text { Tahun yang dicari dengan }\end{aligned}$




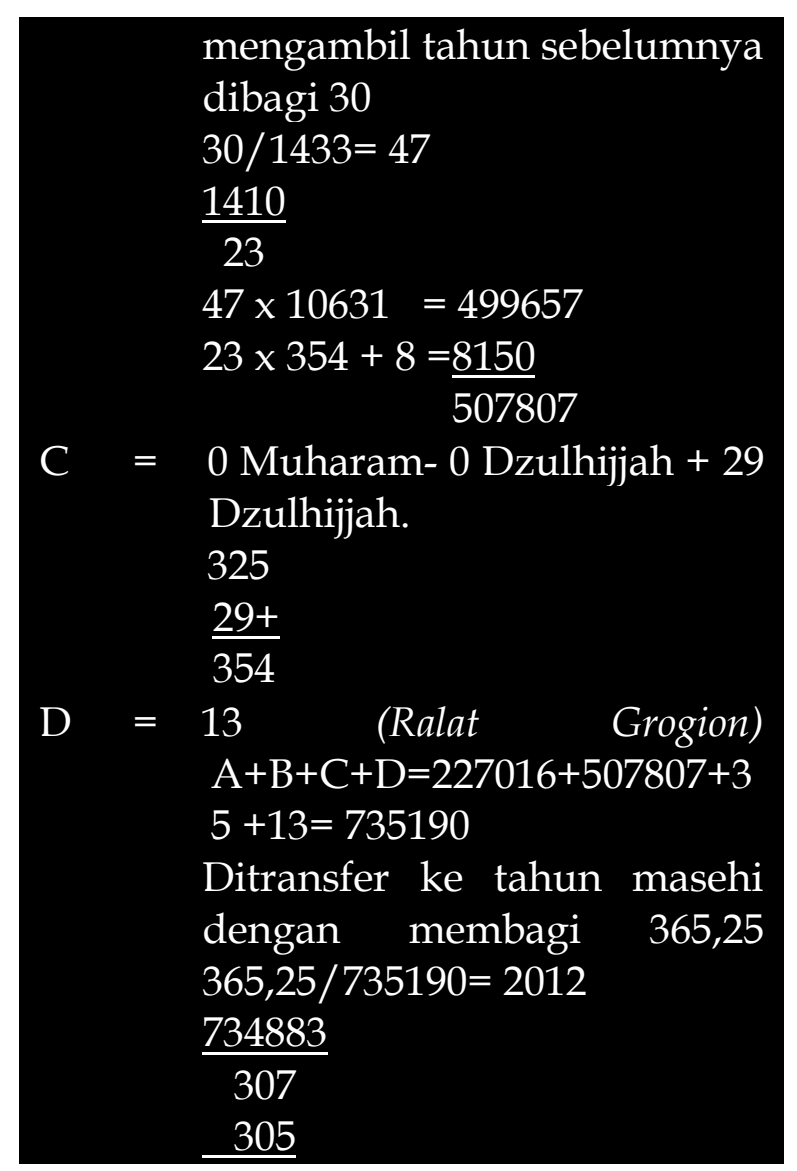

2 November 2013 jatuh pada hari sabtu Hijriyah

\begin{tabular}{|c|c|}
\hline 1. & $\begin{array}{l}\text { Menentukan saat terjadi ijtimak } \\
\text { Jam FIB+ELM-ALB+7 jam WIB } \\
\text { SB-SM } 00^{\circ}+\left(232^{\circ} 01^{\prime} 16^{\prime \prime}-\right. \\
\left.233^{\circ} 06^{\prime} 25^{\prime \prime}\right)+70^{\circ} 37^{\prime} 57^{\prime \prime}-0^{\circ} 02^{\circ} 32^{\prime \prime} \\
0^{\circ}\left(-1^{\circ} 50^{\prime} 22,31^{\prime \prime}\right)+75^{\circ} 9^{\prime} 37,69^{\prime \prime} .\end{array}$ \\
\hline 2. & $\begin{array}{l}\text { Menghitung sudut waktu } \\
\text { matahari cost* }=\tan \left(-0^{\circ} 27^{\prime}\right) \times \\
\tan \left(18^{\circ} 23^{\prime} 19^{\prime \prime}\right)+\sin \left(-1^{\circ}\right): \cos (- \\
\left.0^{\circ} 27^{\prime}\right): \cos \left(-18^{\circ} 23^{\prime} 19^{\prime \prime}\right) 90^{\circ} 8{ }^{\prime} 59,37^{\prime \prime} .\end{array}$ \\
\hline 3. & 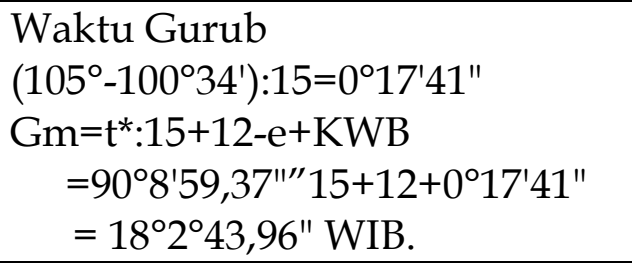 \\
\hline 4. & 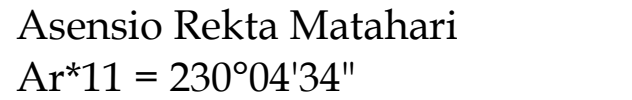 \\
\hline
\end{tabular}

\begin{tabular}{|c|c|}
\hline & $\begin{array}{l}\mathrm{Ar}^{*} 12=\frac{230^{\circ} 07^{\prime} 08^{\prime \prime}-}{0^{\circ} 2^{\prime} 34^{\prime \prime}} \\
\mathrm{Ar}^{*}=230^{\circ} 04^{\prime} 34^{\prime \prime}+00^{\circ} 2^{\prime} 43,56^{\prime \prime} \times(- \\
\left.0^{\circ} 2^{\prime \prime} 34^{\prime}\right) \\
\quad=230^{\circ} 4^{\prime} 27^{\prime \prime} .\end{array}$ \\
\hline 5. & 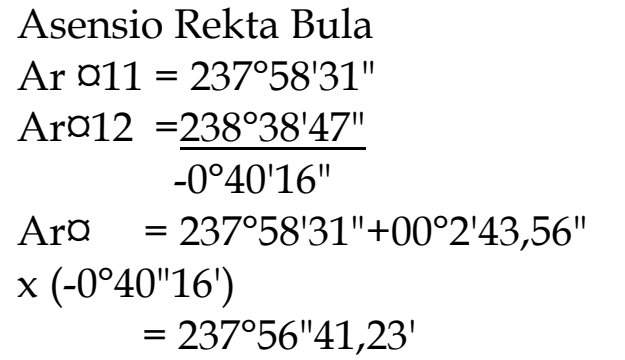 \\
\hline 6. & $\begin{array}{l}\text { Sudut Waktu Bulan } \\
\text { to }=230^{\circ} 4^{\prime} 27^{\prime \prime}- \\
\begin{array}{l}237^{\circ} 56^{\prime} 42,23^{\prime \prime}+90^{\circ} 8^{\prime} 59,37^{\prime \prime} \\
\quad=82^{\circ} 16^{\prime} 45,14^{\prime \prime}\end{array}\end{array}$ \\
\hline 7. & 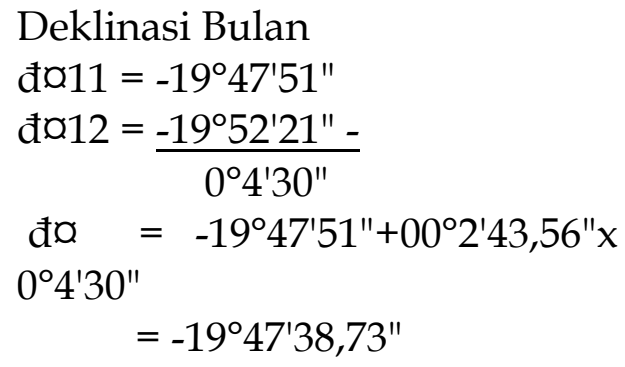 \\
\hline 8. & $\begin{array}{l}\text { Tinggi Hilal Hakiki } \\
\text { Sin } \mathrm{h} \mathrm{d}=\sin \varphi \times \operatorname{sind}+\cos \varphi \times \\
\cos \mathrm{d} \times \cos \mathrm{x}=\sin \left(-0^{\circ} 27^{\prime \prime}\right) \times \sin (- \\
\left.19^{\circ} 47^{\prime} 38,73^{\prime \prime}\right)+\cos \left(-0^{\circ} 27^{\prime}\right) \times \cos \\
\left(-19^{\circ} 47^{\prime} 38,73^{\prime \prime}\right) \times \cos 82^{\circ} 16^{\prime} 45,14^{\prime \prime} \\
-0,00785 \times(-0,33864)+0,99997 \times \\
0,94092 \times 0,13435 \\
0,12907 \\
\begin{array}{r}\mathrm{H}=7,41585 \\
=7^{\circ} 24^{\prime} 57,06^{\prime \prime} .\end{array}\end{array}$ \\
\hline
\end{tabular}




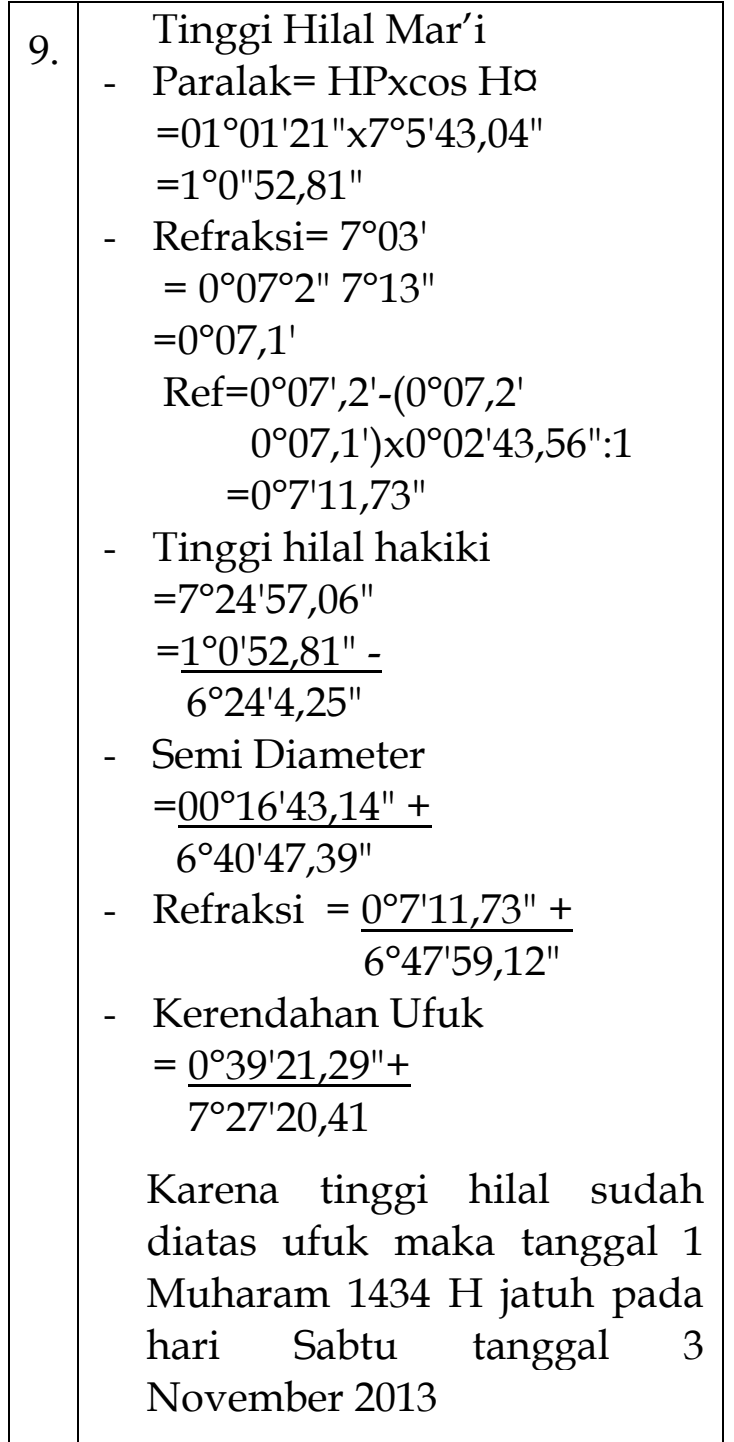

Berdasarkan hasil hisab hakiki dan hisab taqwim di atas maka dapat dipahami bahwa:

1. Hasil hisab hakiki sama dengan hasil taqwim jika dihitung dengan memulai hitungan pada hari kamis

2. Hasil hisab taqwim lebih dahulu 1 hari darpada hasil hisab hakiki, jika hisab taqwim memulai hitungannya pada hari Rabu.

Hisab taqwim digunakan bukan untuk menentukan waktu jatuhnya awal bulan baru, tetapi hanya untuk menetukan jatuhnya tanggal 29 akhir bulan dalam rangka menetapkan waktu pengamatan hilal. Jika hilil sudah nampak hisab tidak dilakukan, dan jika hilal tidak nampak maka hitungan bulan digenapkan 30 hari. Jadi hisab bukanlah menjadi patokan dalam penentuan awal bulan Hijriyah. Hisab hanya sebatas untuk mengetahui waktu akhir bulan qamariyah, tidak sampai pada tingkat mengitung waktu ijtima' dan ketinggian hilal seperti pada hisab hakiki.

Melaksanakan rukyat cara yang digunakan belum memenuhi kriteria pengamatan hilal secara ilmiah, karena pengamatan hilal hanya dilakukan dengan mata telanjang. Sementara pengamatan hilal saat ini sudah menggunakan pesawat teodolite.

\section{PENUTUP}

\section{Kesimpulan}

1. Dalam naskah Mizan Al-Qarb ada dua metode dalam penentuan awal bulan Hijriyah yaitu rukyat dan hisab (taqwim). Dari dua metode tersebut yang dijadikan acuan dalam penetapan awal bulan Hijriyah adalah rukyat.

2. Jika menggunakan hisab taqwim, dengan memulai hitungan pada hari Kamis, maka akan sama hasilnya dengan hisab hakiki kontemporer. Jika memulai hitungan pada hari Rabu, akan selisih 1 hari dengan hisab hakiki kontemporer.

3. Pengamatan hilal dilakukan tanpa menggunakan media, tetapi hanya dengan mata telanjang.

\section{Saran}

1. Sebagai salah satu literature dalam Ilmu Falak, sebaiknya naskah Mizan al-Qarb dipelihara secara baik agar 
tidak musnah, bagaimanapun keberadaannya sudah terukir dalam keberagaman pemahaman keagamaan di Indonesia

2. Sebagai lembaga yang berwenang Kementerian Agama seharusnya juga mengayomi penganut aliran-aliran keagaamaan, apalagi yang menyangkut persoalan penetapan awal bulan Hijriyah, dan tidak membiarkan mereka terus hanyut dalam perbedaan.

\section{DAFTAR KEPUSTAKAAN}

Akhimuddin, Yusri. 2012. Naskah [Asal Khilaf Bilangan Taqwim]: Relasi Ulama-Umara di Minangkabau Abad ke-17 dalam Penetapan Awal Ramadhan", Laporan Penelitian Short Course Penelitian Filologi Tingkat Nasional tahun.

Azhari, S. (2001). Ilmu Falak Teori dan Praktek (Cet.ke-1st ed.). Yogyakarta: Lazuari.

Azhari, S. (2007). Hisab da Rukyat Wacana untuk Membangun Kebersamaan di tengah Perbedaan (Cet. Ke-1). Yogyakarta: Pustaka Pelajar.

Fuhaidah, U. (2018). Tariqa and Philanthrophy: The Study of Tariqa Qadiriyah Naqsyabandiyyah Movement in Kuala Tungkal, Jambi. Insaniyat Journal Of Islam and Humanities, 3(1).

Izzuddin, A. (2012). Aneka ragam Hisab Rukyat di Indonesia (makalah). Bogor.

Khazin, M. (2005). Ilmu Falak dalam Teori dan Praktek (Cet.ke-3rd ed.). Yogyakarta: Buana Pustaka.

Nur, N. (1996). Ilmu Falak. Diktat.
Rachim, A. (1983). Ilmu Falak (Cet.ke-1st ed.). Yogyakarta: Liberty.

Moh. Muhtador. (2017) Rethinking of Islamic Sufism: Sufisme Sebagai Solusi Alternatif ata Kekerasa Sosial. Kudus. Esoterik:Jurnal Akhlak dan Tazawuf.ISSN:2460-7576 EISSN 25028847(DOI:10.21043/esoterik.v3il.387 7). 